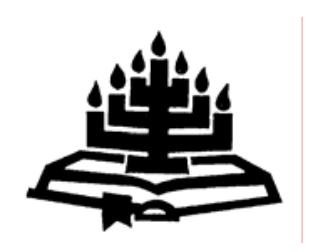

\title{
Providence, conscience of liberty and benevolence - the implications of Luther's and Calvin's views on natural law for fundamental rights
}

\author{
Andries Raath \\ Department of Constitutional Law and Philosophy of Law \\ University of the Free State \\ BLOEMFONTEIN \\ E-mail: raathA.RD@mail.uovs.ac.za
}

\begin{abstract}
Providence, conscience of liberty and benevolence - the implications of Luther's and Calvin's views on natural law for fundamental rights

Prof. Johan van der Vyver recently identified a need for a Scriptural foundation of human rights. In this article it is argued that together with their evangelical perspectives, Luther's and Calvin's Ciceronian re-interpretation of Thomism produced very important perspectives for establishing the moral context of a Scriptural basis for fundamental rights and duties. The implications of the views of both Luther and Calvin on fundamental duties and justice presuppose a moral context from which issues related to human rights can be approached. In that regard the views of Luther and Calvin still have much to contribute towards developing an evangelical approach to human rights.
\end{abstract}

Opsomming

Voorsienigheid, bewussyn van vryheid en welwillendheid die implikasies van Luther en Calvyn se standpunte oor die natuurreg vir fundamentele regte

Prof. Johan van der Vyver het onlangs die behoefte aan 'n Skriftuurlike grondslag vir menseregte geïdentifiseer. In hierdie artikel word geargumenteer dat Luther en Calvyn se Ciceroniaanse herinterpretasie van die Thomisme tesame met hulle evangeliese perspektiewe, baie belangrike moontlikhede geopen het vir die bepaling van die morele konteks van 'n Skriftuurlike basis vir fundamentele regte en verpligtinge. Die impli- 
kasies van sowel Luther as Calvyn se standpunte oor fundamentele pligte en geregtigheid veronderstel 'n morele konteks van waaruit aangeleenthede met betrekking tot menseregte benader kan word. In dáárdie opsig het Luther en Calvyn se standpunte steeds baie vir die onderwerp van 'n evangeliese benadering tot menseregte te sê.

\section{Introduction}

In a recent article on human rights in Koers, Prof. Johan van der Vyver of Emory University critically investigates the question of whether human dignity can adequately serve as the basis for fundamental rights protection. Together with his rejection of human dignity serving as "the most fundamental basis of human rights protection", he identifies a need for a Scriptural foundation of human rights (Van der Vyver, 2005:455-471). The lament of Van der Vyver's demands the urgent attention of evangelical academics earnestly engaging with issues related to human rights and the foundations thereof.

In this article it is argued that the views of Martin Luther and John Calvin on providence, liberty of conscience and benevolence - although not novel in all fundamental respects - do provide the "connecting points" for developing a basis (or foundation) for theorising on human rights in the Reformational fold. In order to identify possible points of connection for theorising on human rights, an indepth analysis of human conscience, the Spirit of God within the sphere of divine providence, and the nature and role of natural law and natural rights in their interrelatedness is required.

\section{Human conscience and the spirit of liberty}

\subsection{Providence and the tradition of natural law}

\subsubsection{Cicero and Aquinas on law and divine providence}

In his digression from Aristotle's views on the non-involvement of the divine in human affairs, Cicero, in a well-known passage in his work on Laws, traces the government of nature to divine providence: the "might of the immortal gods, or by their nature, reason, power, mind, will" (Leg. ${ }^{1}$ 1.7.22). The providence of God extends to the divine

1 The following abbreviations for the works of Cicero are used: De Legibus (Leg.); De Officiis (Off.); Oratio in Catilinam (Cat.); De Finibus (Fin.); Orationes 
creation of man with foresight and "quick intelligence", "complex, keen, possessing memory, full of reason" (Leg. 1.7.22). Reason, to Cicero, represents a divine element in man; and reason, when it is perfected, is rightly called wisdom (Leg. 1.7.23). Cicero infers that there is nothing better than reason, and since it exists in both man and God, the first common possession of man and God is reason. He then proceeds to argue that those who have reason in common must also have right reason in common; and since right reason is Law, it must be believed that men have Law also in common with the divine. In fact, reason is an element common to both God and human beings (Leg. 1.7.23).

In his Summa Theologica Thomas Aquinas (1997) expresses Law as right reason in terms of God's providential eternal law (lex aeter$n a)$ : because the whole community of the universe ${ }^{2}$ is governed by divine reason, the very idea of the government of things in God the Ruler of the universe has the nature of a law; and since the divine Reason's conception of things is not subject to time but is eternal, according to Proverbs 8: 23, this kind of law must therefore be called eternal (ST P(1-2) Q(91) $\mathrm{A}(1)$ ).

The arguments of both Cicero and Aquinas in favour of divine providence reflect an effort to relate the divine activity in creation and providence to the eternal mind of God. Aquinas' reference to Proverbs 8:23 makes the point that divine wisdom exceeds the finite capacity of the human mind: no one is able to know the eternal law in its essence, except the perfected souls in heaven who are able to see God in his essence. However, this does not exclude the ability of humans, as rational creatures, to know it more or less, in its reflection (ST $\mathrm{P}(1-2) \mathrm{Q}(93) \mathrm{A}(2)$ ). Although God's pattern of wisdom exceeds man's rational ability, God offers mankind the reflections of natural and divine law expressive of his eternal Reason. Both Cicero and Aquinas express man's knowledge of natural law in terms of natural law imprinted on the deepest structures of man's being (heart or conscience). After stating that man "is born for Justice" and that right is not conventional but rather is based upon "Nature", Cicero argues that the "rudimentary beginnings of intelligence" are imprinted on all minds alike (Leg. 1.10.31). The corruption of

Philippicae (Phil.); Epistolae ad Familiares (Fam.); Oratio in Pisonem (Pis.); Oratio pro Cluentio (Clu.); De Natura Deorum (ND.); Epistolae ad Atticum (Att.).

2 Thomas implicitly alludes to Cicero's remarks in Leg. (1.7.23) to the effect that those who share law and justice are to be regarded as "members of the same commonwealth". 
mankind caused by bad habits is so great "that the sparks of fire", so to speak, which nature has kindled, are extinguished by "this corruption" (Leg. 1.12.33). Those creatures who have received the gift of reason from nature have also received right reason, and therefore they have also received the gift of law, which is right reason applied to command and prohibition (Leg. 1.12.33).

Parallel to the view of Cicero in favour of the "rudimentary beginnings of intelligence" and the "sparks of fire" of divine reason reflected in man, Aquinas explains man's "participation of the eternal law", alluding to the words of Psalm 4:6, as meaning that man discerns what is good and evil, which is the function of the natural law, as being nothing other than the imprint on man of the divine light. From this Aquinas concludes that natural law is nothing other than man's participation in the eternal law (ST $\mathrm{P}(1-2) \mathrm{Q}(91) \mathrm{A}(12))$.

\subsubsection{Luther and Calvin on natural law and providence}

The view that man's innermost being bears "remnants" or "sparks" of divine justice is also reflected in the natural law perspectives of both Luther and Calvin. In his commentary on St. Paul's epistle to the Romans, Luther discerns natural law as being inscribed in the hearts of men by the Holy Spirit. The evangelical basis of Luther's argument is that natural law is the divine law instilled in man's heart as the result of God's creational work ${ }^{3}$ and as a reflection of God's righteousness. In his Lectures on the Psalms, Luther relates the "divine stations and orders" to God's righteousness enduring forever. God's righteousness, reflected in the precepts of natural law, serves the purpose of ensuring that the world may be stable and that an orderly, and peaceful life may be ensured and justice 4 may be preserved (LW 13:369 (LP Psalm 112)). 5

3 For the interpretation and development of the Pauline-Augustinian tradition of natural law by Luther, cf. Raath (2005:425-454).

4 For justice in Luther's theology, cf. Raath (2006b:335-354).

5 The following abbreviations are used, together with the relevant Scriptural citation where applicable, for citing Luthers individual works in the American edition (Luther, 1958-1967): Lectures on Genesis (LG); Selected Psalms (SP); Lectures on Galatians (LGS); Sermon on the mount and the magnificat (SM\&M); Sermons on the Gospel of St. John (SJ); The confession concerning Christ's supper (CCS); An exhortation to the Knights of the Teutonic Order (ETO); Sermons (S); Table talk (TT); Lectures on the minor prophets (LMP); Treatise on good works (TGW); The Catholic Epistles (CE); Lectures on Titus, Philemon and Hebrews (TP\&H); Admonition to peace: a reply to the twelve articles of the 
Luther's views on man's rational abilities to access the precepts of natural law are reminiscent of Cicero's appeal to man's rational functions to gain knowledge of the creationally-instilled natural law precepts. Therefore, to Luther, natural law is, in principle, accessible to reason ( $L W 45: 129$ (TO)), and because of the central function of man's reasoning in gaining knowledge of the content of natural law, even the gentiles have a rational knowledge of the precepts of natural law ( $L W$ 22:150 f. (SJ), John 1). An additional parallel to Cicero's arguments supportive of the "rudimentary beginnings of intelligence" being subject to "man's corruption" and nature's gift of right reason, is found in Luther's appeals to the work of the Holy Spirit for enlightening man's rudimentary knowledge of natural law ( $L W 46$ : 242 (SCS); WA 11:280 (Predigten und Schriften, 1523); 17(2):91 (Fastenpostille, 1525); 30(2):562 (Schriften, 1529/30)).

Although (similar to Luther) Calvin's discussions of natural law, in comparison with the medieval tradition, seem imprecise and unsystematic because "he neither provided a systematic treatment of natural law nor did he analyse many of the issues commonly discussed by ancient and medieval thinkers", he did remark extensively on the nature and functions of natural law (Schreiner, 2001:77). In his Institutes, Calvin alludes to natural law as the "inward law" (lex illa interior) engraved (impressam) "upon the hearts of all", and in his comments on Romans 2:14-15, he states that the gentiles also, "beyond doubt" have certain conceptions of justice and rectitude which are naturally inborn (naturalites ingenita) in the minds of men (Schreiner, 2001:77). Because of man's sin, the divine law (in the form of the Decalogue) is necessary to clarify that which man's fallen reason can no longer understand (Schreiner, 2001:78). Similar to the argument of Aquinas that natural law is required, from a providential perspective, to restrain those natural and human forces which threaten to annihilate the human race, Calvin subscribes to the principle that God remains true to his own purpose in creation by

peasants of Swabia (AP); Whether soldiers, too, can be saved (SS); The bondage of the will (BW); Word and sacrament (W\&S); A sermon on keeping children in school (KCS); On the councils of the church (CC); Personal prayer book (PB); An exposition of the Lord's prayer (LP); Trade and usury (TU); On marriage matters (OM); Disputation concerning justification (DJ); Temporal authority: to what extent it should be obeyed (TO); Prefaces to the books of the Bible (PB); Theses concerning faith and law (F\&L); Appeal against the heavenly prophets (HP); Commentary on Romans (CR); The freedom of a Christian (FC); Disputation against scholastic theology (DST). References to WA are to the standard edition of Luther's Werke (1883-1987), and to MA are to his Ausgewählte Werke (1963-2005). 
providentially preserving the stability and order of the realm of creation, which restraint is exercised inwardly through the recognition of natural law (Schreiner, 2001:95).

\subsubsection{Intellect, moral law and continuity of the tradition of natural law}

John McNeill's argument that the subject of natural law was not a source of controversy between the Scholastic tradition and the Reformers, is, generally speaking, true (cf. McNeill, 1946:168-182; also, 1941:211-227). The early Reformational views of Luther and Calvin did not materially differ from the basic teachings of Cicero and the Scholastics regarding the natural law being inscribed on the hearts, or innermost beings, of men; that natural law is a manifestation of God's providence enabling men to distinguish between right and wrong, and that it guides rational creatures in a more excellent way by being provident both for itself and for others (ST P(1-2) $\mathrm{Q}(91) \mathrm{A}(2))$. Neither does there seem to be a difference in opinion between the Ciceronian and Scholastic views on the one hand and Luther's and Calvin's statements on the other regarding the formulation of a providential natural law theory, in terms of which man's deep intellect (heart or conscience) reflects the fundamental moral principles (albeit dimmed by $\sin$ ) providing human beings with the potential to be drawn into the pattern of God's wisdom and thereby making them collaborators to establish justice in the world.

\subsection{Conscience, natural law and moral obligation}

\subsubsection{The Ciceronian and Scholastic views on conscience and moral knowledge}

Cicero's treatment of conscientia is inseparably linked to the moral knowledge gathered by human beings. Such knowledge can be either individual or social in nature. So, for example, Cicero alludes to the common knowledge of senators of a looming conspiracy (Cat. 1.1). 6 Similarly Cicero points to the general knowledge of mankind regarding that which is bad (Fin. 2.9.28). ${ }^{7}$ Elsewhere Cicero links conscience to the circle of common knowledge possessed by people

6 “... nihil concursus bonorum omnium, nihil hic muntissimus habendi senatus locus, nihil horum ora voltusque moverunt?"

$7 \quad$ “... ut hominum conscientia remota nihil tam turpe sit quod voluptatis esse facturus". 
(Phil. 2.11). More often, however, Cicero refers to conscientia as the consciousness, knowledge, feeling or sense someone has; the consciousness of right and wrong, or he uses the term for a good or a bad conscience. In his Epistolae ad Familiares he reminds the addressee of the "consciousness of his services and goodwill" (Fam. $3.7 \mathrm{ff}$.). 8 He also applies the term conscientia to express a person's knowledge of his own crimes (Pis. 17);9 the certainty of punishment for accessories to crimes (Clu. 20.56) ${ }^{10}$ and to denote "the trustworthy voice of own conscience" (Fin. 2.22.71). 11 In his speculations on the nature of the gods, Cicero regards the "innocent" or "guilty" conscience a powerful force in itself (ND. 3.35.85). ${ }^{12}$ In a letter to Atticus, Cicero expresses his deeply held conviction that "(i)n all one's life one ought not to stray a nail's breadth from the straight path of conscience" (Att. 12.20). 13 He also writes to Atticus that his own conscience is of more value to him than the talk of others (Att. 12.28.2). ${ }^{14} \mathrm{~A}$ bad conscience testifies against its bearer, says Cicero (Off. 3.21f.); 15 a bad conscience silences even the boldest of men (Cat. 2.6.13); guilty men are "tormented and pursued by the Furies, not with blazing torches, as in the tragedies, but with the anguish of remorse and the torture of a guilty conscience" (Leg. 1.14).16

8 "Haec ad te scripsi liberius, fretus conscientia offici mei benevolentiaeque, quam a me certo iudico susceptam, quod tu voles conservabo."

9 "Nihil enim mea iam refert, itrum tu, conscientia oppressus scelerum tuorum nihil umquam ausus sis scribere ad eum ordinem, ...".

“... quos venenum etiam consilia conscientiasque ...".

11 "Ita, quod certissimum est pro vera certaque iutitia simulationem nobis iustitiae traditis praecipitisque quodam modo ut nostram stabilem conscientiam contemnamus, aliorum errantem opinionem aucupemur."

12 "... recte videretur, nisi virtutis et vitiorum sine ulla divina ratione grave ipsius conscientiae pondus esset".

13 "... in omni vita sua quemque a recta conscientia transversum unguem non oportet discerede".

14 "Nunc plane nec ego victum nec vitam illam colere possum, nec in ea re, quid aliis videatur, mihi puto curandum; mea mihi cnscientia pluris est quam omnium sermo."

"Hunc ti quas conscientiae labes in animo censes habuisse, quae vulnare?" 
To Thomas, in distinction from synteresis, the basic or original conscience, ${ }^{17}$ conscientia implies the relation of knowledge to something - conscience witnesses, binds, incites, accuses, torments, or rebukes (ST $\mathrm{P}(1) \mathrm{Q}(79) \mathrm{A}(13))$. Therefore, conscience is not a power but a specific function, namely the application of knowledge (ST $P(1) Q(79) A(13)$ ). Conscience, by implication, has the function of practical reason (ST $\mathrm{P}(1) \mathrm{Q}(79) \quad \mathrm{A}(13) \mathrm{RO}(1)-(2))$. 18 Therefore conscientia can be described as that which controls the spirit and guides the soul as a dictate of reason (ST P(1) Q(79) A(13) RO (1)). ${ }^{19}$ In effect it means that conscientia, as the dictate of reason, incorporates a goal-oriented system of knowledge, 20 an act of practical reason in the form of affirmative or negative judgment (ST $P(1) Q(79) A(13)){ }^{21}$

\subsubsection{Luther and Calvin on conscience and the spirit of liberty}

Different from the conception of conscientia of Aquinas, conscience, for Luther, is not the application of the law or knowledge, 22 but the "mystical sphere in which the gigantic struggle for the redemption of the soul takes place", in which the condemning law, 23 the wrath of God 24 and the powers of temptation rage against sinners (Scholer, 1981:269). ${ }^{25}$ The freedom of conscience manifested in the inner

17 Cf. Esser \& Prins (1947:43): "deze laatste is wel de grootste leeraar van dien tijd, ook inzake het geweten. Hy siet daarin ook iets goddelijks n.l. in een deel ervan: de synderesis, de grond, de kern van de conscientia; deze synderesis zou dan zooveel zijn als het goddelijk deel, het feilbaar deel van het geweten ...".

“... conscientia dicitur est actus synteresis idio quandoque positur pro ea".

“... conscientiae dicitur spiritus corrector et apedagogus animae, ed. Set, dictamen rationis".

“... ordo scientiae ad aliquid".

21 '... conscientiae definiri potest iudium rationis affirmantis vel negantis aliquid circa res particularis".

22 “... applicatio legis vel scientiae ...".

23 Lex mortis.

$24 \quad$ Ira Dei.

25 Cf. WA (27:152.4): “... ubi expedita illa officiana Exercet suam potentiam et opera in illo homine qui quam sit frigidus et piger in exequenda lege, agnoscit, qui nihil quam iram et indignationem adeoque eternam damnationem sentit ac iuditium". 
recesses of the conscience, to Luther, concerns Christian freedom experienced as a result of justification based on faith. The conscience of freedom is only possible through the Word, faith and the working of the Spirit in the inner recesses of man's being. Therefore men should guard against the weakening of faith by wicked laws and tyrants ( $L W$ 36:250 (BKS)). Breaking the bonds of conscience ensnared by evil is only possible through "preaching, lecturing, observing, discussing, writing, and hearing the gospel" in promoting love according to the will of God (LW 36:250, $255 \mathrm{ff}$. (BKS)).

The weak conscience, to Luther, should be strengthened by faith and trust, "so that we not only look upon the judgment of the whole world as straw and chaff, but also that in death we may be adept in fighting against the judgment of God, and with Jacob prevail against God through such strong faith (LW 36:134 (MM)). The mighty and true Word of God is a primary instrument to guard and protect us from enslaving our conscience ( $L W$ 36:134 (MM)). Love through faith is important for freeing the human conscience from "the impositions of the devil". It assists in using the conscience wisely and subjecting it in service of our neighbour "that we may bring him also to that same freedom of conscience" (LW 36:261 (BKS)). Faith and love are essential for conscience of freedom, because faith, intent on the immutable truth of God, makes the conscience tremble, "terrifies it and bruises it", but afterwards, when it is contrite, raises it up, consoles it, and preserves it ( $L W 36: 84(B C C)) .26$ The conscience of freedom contains an element of mystical experience of the Word and of Christ. In his Receiving both kinds in the sacrament, Luther remarks that "(i)t is not enough that you say: Luther, Peter, or Paul has said this; but you yourself in your own conscience must feel Christ himself. You must experience unshakably that it is God's Word, even though the whole world should dispute it." Luther adds: "As long as you do not have this feeling, just so long you have certainly not yet tasted of God's Word." (LW 36:248 (BKS).) In his Judgment of Monastic vows (1521), Luther describes the evangelical freedom flowing from the experience of freedom as a freedom of works. Christ has freed this conscience from works through the that which is good or bad. In the Not- und Hülfs-Büchlein (Anon., 1814:246), the function of the conscience is described as follows: "Das Gewissin ist nämlich nichts anders, als die Meinung, die wir selbst von unserm eigen Thun und Lassen haben, ob est recht oder unrecht sey. Dabey ist uns wohl zu Muthe, wenn wir recht gethan haben, und es drückt uns im Hertzen, wenn wir unrecht gethan haben. Und das heiszt man ein gutes oder böses Gewissen." 
gospel and teaches this conscience not to trust in works, "but to rely on his mercy" ( $L W$ 44:298 (JMV)). He adds that the liberated conscience "belongs to Christ and Christ to the conscience, and no one intrudes into the secret bedchamber of this spouse and his bride" (LW 44:303 (JMV)). ${ }^{27}$ It is noteworthy that Luther's views on God speaking through natural law in the conscience of man, are almost a direct blueprint of Augustine's statement to the effect that God, who inscribed the eternal law (Lex aeterna) on the hearts or souls or minds of all men, speaks to everyone through the lex naturalis in providing man with the required moral knowledge to make decisions in furthering the love of God and one's neighbour.

Calvin broadly followed the Lutheran view in his distinction between the spiritual and civil realms and man's freedom of conscience through the working of the Holy Spirit. In his Institutes, Calvin, commenting on the two governments (the spiritual and the civil) in the world, states that although the consciences of Christians have been set free in God's sight, experiencing freedom according to the Spirit, they are not released from their duties, obligations and responsibilities in the civil sphere. Therefore, freedom of conscience does not separate believers from coexistence with the wicked in the world, but that only "certain beginnings" of the heavenly kingdom or the "spiritual government" have been initiated upon the earth (Inst2. 4.20.1; Inst. 6.35). 28

Both Luther and Calvin maintain God's involvement with the order of creation - God guides history, He is true to the work of his hands, and $\mathrm{He}$ remains faithful to his purposes with and in creation. Although the created order was seriously affected by sin, God reveals Himself through the Word and in nature. The Spirit of God is instrumental in revealing God's providence, grace and care. Although Luther, more so than Calvin, believes that God brought all of creation into being through the Word and that God continually sustains, preserves, governs and works through every creature, the implications of the arguments of both are that man's correct relationship to God is of fundamental importance for understanding creation and doing God's will. Although fallen humanity retains a conscience, a

27 Scholler (1981:27) concludes that the Lutheran concept of conscience is not in accordance with the synteresis or conscientia of Scholasticism; rather, it displays certain characteristics of German mysticism.

28 All references are to Calvin's 1559 edition of his Institutes, except where otherwise indicated. 
knowledge of natural law, and the ability to regulate society, it has lost the perfect, instantaneous, knowledge of God, nature, and society characteristic of the prefallen world; humanity now responds to God's words and works primarily in faith.

\subsection{The spirit of liberty and moral duties}

\subsubsection{Cicero and Aquinas on benevolence and moral duty}

The moral context of natural law, to Cicero, is determined by its being social in nature. In his work On laws Cicero holds law to be the intelligence, whose natural function is to command right conduct and forbid wrongdoing (Leg. 1.5.19). This quality, says Cicero, is derived from the idea of choosing (Leg. 1.5.19). Because law is a natural force found in the mind and reason of the intelligent man, it is the standard by which justice and injustice are measured (Leg. 1.6.19). The fact that man is born for justice and that right is based, not upon man's opinions, but upon nature, is illustrated and highlighted by man's fellowship and union with his fellow-men (Leg. 1.10.28-29). This implies that there are certain qualities imprinted on all minds alike, enabling all men to attain to virtue - including justice as the supreme virtue (Leg. 1.10.30). Similarly all men shun death, cling to life, and look upon pain as "one of the greatest of evils, not only because of its cruelty, but also it seems to lead to the destruction of nature" (Leg. 1.10.31). Inasmuch as the whole human race is bound together in unity, it follows that knowledge of the principles of right living is what makes men better (Leg. 1.11.32). ${ }^{29}$ The whole of mankind, to Cicero, is so constituted by nature "as to share the sense of justice with one another and to pass it on to all men" (Leg. 1.12.33).

Following his statement that man is divinely endowed with both reason and right reason, and that, therefore, man has received the gift of law, Cicero accords benevolence the status of a supreme virtue: when a wise man shows benevolence towards another, he does not love himself more than he loves the other, because all men are in fact equal. If, on the other hand, a distinction should be made in friendship, then friendship (and benevolence as such) would disappear (Leg. 1.12.34); "for its essence is such that, as soon as either friend prefers anything for himself, friendship (and benevolence) ceases to exist" (Leg. 1.12.34). Cicero adds that there is 
only one principle by which men may live with one another, and that is the same for all, and possessed by all: that all men are bound together by a natural feeling of benevolence and by a partnership in justice (Leg. 1.13.35). The implications of Cicero's argument thus far may be summarised as follows: the conscience plays an important role in maintaining the "firm foundation of states, the strengthening of cities, and the curing of the ills of peoples" (Leg. 1.13.37), in so far as contravention of the law brings torment of man's conscience in its wake, thereby providing him with the knowledge of his immoral conduct (Leg. 1.14.40). The promotion of justice originates in man's natural love for his fellow-men - this is the foundation of justice (Leg. 1.15.43), and to live according to this principle of benevolence is the highest good (Leg. 1.21.56).

Aquinas also reverts to benevolence as the basis of justice. Alluding to Aristotle, Aquinas states that not every love has the character of friendship, as does that love which goes with benevolence, when we love someone so as to wish good to him. If, on the other hand, we do not wish good to what we love, but wish its good for ourselves, it is love not of friendship, but of a kind of conscupiscence. Aquinas adds: "Yet neither does well-wishing suffice for friendship, for a certain mutual love is requisite, since friendship is between friend and friend, and this well-wishing is founded on some kind of communication." The application of benevolence reflects certain core-elements: equal treatment of all ( $S T \mathrm{P}(2-2) \mathrm{Q}(26) \mathrm{A}(6) \mathrm{RO}(1))$; man rejoices in the well-being of others ( $S T P(2-2) Q(28) A(1)$ ); Christ forbids the judgment which proceeds not from benevolence but from bitterness of heart (,, $\mathrm{P}(2-2) \mathrm{Q}(60) \mathrm{A}(2) \mathrm{RO}(1))$; it is lawful to exact compensation from a loan, in respect of such things that are not appreciated by a measure of money, for instance benevolence and love for the lender (ST $\mathrm{P}(2-2) \mathrm{Q}(78) \mathrm{A}(2))$; all loans should be made with a feeling of benevolence (ST P(2-2) $A(2) R O(3)$ ); it belongs to the essence of justice (according to Aristotle's (1977) Ethics 8 \& 9) to direct our external conduct towards others benevolently ("affectionately"), to promote peace ("concord"), and behave humanely ("beneficiently" (ST $\mathrm{P}(2-2) \mathrm{Q}(80) \mathrm{A}(1) \mathrm{RO}(2)$ ), and lying is opposed to benevolence (or justice) (ST P(2-2) Q(110) A(1)).

\subsubsection{Luther and Calvin on benevolence and moral duty}

Luther's perspectives on natural right run parallel to the Ciceronian view that human life is universally subject to moral duties, that no aspect of life, whether in private or in public, can be without the pertaining moral duties, that on the discharge of such duties depends all that is morally right, and on their neglect all that is morally wrong 
(Off. 1.2.4). From an evangelical perspective to Luther, this entails that man lives subject to the twofold duty of love - love towards God and towards one's neighbour. These two duties of love form the basis of man's moral duties. The duties of love, transposed in a social context to the duty of benevolence towards your neighbour, are stamped on the deeper structures of human beings in the form of moral precepts that have universal application in all spheres of human existence. In his reflections on Galatians 5:14 the duty-based nature of natural law in Luther's theology is expressed in terms of the natural knowledge that is implanted in the minds of men, 30 by which they know naturally that one should do unto others what one wants done to oneself. 31 This principle and others like it, which we call the law of nature, are according to Luther the foundations of human laws and all good works (LW 26:53 (LGS Galatians 1)). Duty-based rights are needed for man to fulfil his calling and duty towards God and to live in peace with his fellow-men. Natural rights, therefore, are divine rights because they are sanctioned by God, stamped on man's conscience in the form of duty-based entities, and enforceable within specific moral limits, to serve God and one's neighbour. God's divine law is a statement of supreme truth, and it transcends human manipulation, knowledge of which is gained through the Holy Spirit (cf. LW 11:507 (LP Psalm 119)).

The voice of justice (God's law of truth) will continuously be heard, because the law of justice makes itself heard by all human beings (albeit not to the same degree) through the working of the Holy Spirit. God's voice of justice is reflective of God's merciful and benevolent providence towards mankind. Being sensitive to and attentatively reflecting on God's providential government of the world, opens the way for introducing the virtues of love, justice and benevolence into human society.

The notion of duty-based natural rights in Luther's theology serves two important functions: firstly, it presupposes that man has rights in order to discharge duties towards God and his fellow-men; secondly, the most fundamental right anyone can have is the right to freedom of conscience, based on man's conscience of freedom. By implication this means that conscience itself does not have an absolute freedom, but that the human conscience as natural right has the 
absolute right to distinguish between right and wrong and to act according to the divine will. The fundamental (or "connatural") right to freedom of conscience presupposes the authority to act, protected by the moral law which obliges others to respect that faculty.

The human mind enlightened by faith, to Calvin, opens man's eyes to perceive the love and benevolence of God. The renewed mind can perceive more and more clearly that God is a "propitious Father" whose benevolence and goodness are beyond doubt. Since believers know themselves to be God's children, they are no longer uncertain about God's love towards them, nor even about their own perseverance (Inst2. 3.2.14.15; 3.2.38). Such certainty, available to the purified perception of the mind, allows believers to cry, "Abba Father!" The pious Christian desires to live according to an ordered life and contributes to the gradual restoration of an ordered world. Christians live, therefore, according to the natural law in the fullest sense of the term; believers obey the law of nature (ordre de nature), not primarily because of the restraint and shame it imposes, nor because of the mere necessity of survival it guarantees, but out of love, because such a life promotes the will and glory of God. The elect understand (and appreciate) the coherence in the order of nature, the revealed law of God, and the example manifested in the life of Christ. Christians live "according to nature" precisely because they are being returned to the nature intended for them by their Creator. The original nature demands that all intellectual and social activities of the Christian be redirected to their proper goal, namely, the praise of God.

The enlightened and redeemed human mind enables Christians, through a life of charity and justice, to restore and reconstruct society to order and to the praise of God. This demands selfsacrifice because the imitation of Christ is not an individualistic, isolating pursuit but a social ordering of the world, and a life of service and love of the neighbour, a re-establishing of justice and a relieving of poverty. Until the end of the world the elect have the divine duty to work for the good of the neighbour, the upbuilding of the church, and the restoration of society. The ordered and sanctified life of the Christian reflects order, stewardship, service, charity, equity, and justice towards the glory of God. 


\section{The implications of Luther's and Calvin's views on natural law and God's providential government of the world}

\subsection{Luther and Calvin on natural law and natural rights}

\subsubsection{Luther's and Calvin's use of natural law}

Similar to Cicero's interchangeable use of the terms ius naturae, ius naturale, lex naturae and lex naturalis, Luther and Calvin do not have a clearly distinguished meaning attached to each of these terms. Throughout his sermons and commentaries Luther uses ius or lex interchangeably to denote the precepts of natural law for instance. In his commentary on Ecclesiastes 1:1, Luther observes that according to Genesis 1:28 earthly things have been subjected to the ius naturae (natural law or human reason): "this has been, is, and must remain the source, the criterion, and the end of all laws, whether political or domestic" (LW 15:5 (ES Ecclesiastes 1)). ${ }^{32}$ Although the ius naturae may be sufficient for legal purposes, it is insufficient for gaining spiritual insight into matters. So, for example, Luther says that although the canonists define wedlock as the union of male and female, in accordance with the law of nature, this is a poor and weak definition for purposes of theology because it has to be added that marriage is not only an inseparable union of male and female in accordance with the law of nature, but also according to God's will and pleasure (LW 4:222 (LG Genesis 24)). ${ }^{33}$ In a religious sense the ius naturae (natural law) does not denote what happens but what ought to happen. In his Table talk Luther argues as follows: lawyers don't properly define the ius naturale that is common to men and beasts, for it is necessary to distinguish between man as lord and the other animals, and a more excellent quality must be attributed to man. Accordingly the lawyers would express it better if

32 WA (0.8.19 ff.; Vorlesung über den Prediker Salomo, 1526): "Igitur hunc librum Ecclesiasten rectius nos vocaremus Politica vel Oeconomica Salomonis. Non Sane quod leges ferat aut condat regendae vel civitatis vel familiae (Hoc enim abunde praestat ius naturae seu ratio humana, cui subiecta sunt res terrenae, Gene. 1., quae et fons et iudex et finis semper fuit, est et manere debet omnium legum tam politicarum quam omesticarum." Elsewhere Luther also alludes to natural law as the "fountainhead" of all law, because, says Luther, laws and civil rights flow from the fountainhead of natural right ( $L W$ 4:218 (LG Genesis 24)).

WA (43.294.40; Genesisvorlesung): "Theologia aliter definit. Coniugium est coiunctio unius maris et unius foeminae inseparabilis, non tantum iuris naturae, sed etiam volunatis." 
they said that in one case natural law is brutish and in the other case it is rational. He adds that there is no law in the animal but only in man, and therefore they should call it natural law, for law is what ought to happen. So for example, five and three ought not to be eight but are eight. It is also improper to say that natural law is in the animal because the animal protects itself, for the animal does this of its own accord and because it is its nature to do so. Acts are therefore characteristic of animals: law is not, because law exists only in man. To beget and to feed are acts and not law. One would not say to a sow, "you must eat", for it eats without being told. Properly speaking, therefore, lawyers have no natural law but only civil law, which flows out of human reason. Laws are not things that are about to happen of their own accord, for example an apple tree bears fruit without my telling it to. In theology, however, natural law is not what happens but what ought to happen, while lawyers apply the term to what happens and not what ought to happen or is demanded. "Besides, if natural law is attributed to man, as lawyers hold, everything will be mixed up" (LW 54:103 (TT No. 581: Lawyers and theologians, and natural law, Summer or Fall, 1533)).

In his commentaries on Genesis 25, Luther describes the lex naturalis as the law which is common to all nations. In terms of the lex naturalis the rule is assigned to the first born ( $L W$ 4:387 (LG Genesis 25)). Nevertheless, God, the Author of the law, has the sovereign power to make exceptions from the law ( $L W$ 4:387 (LG Genesis 25)). The moral law which was transmitted to the Jews is impressed upon all people, Jews and gentiles, and to this law all people are bound. Therefore the Lord says in Matthew 7:12: "Whatsoever you wish that men would do to you, do so to them, for this is the Law and the Prophets." This transmitted law is the lex naturalis, the natural law, which cannot be unknown to anyone and on account of which no one can be excused (LW 25:180 (LR Romans 2)).

Luther's use of natural law reflects his desire to shift the emphasis from the faculties of human nature to God's providential government of the universe. For this reason God's revelation is not limited to Christians only, and neither is natural law exclusively applicable to the gentile nations. Both gentiles and Christians have certain conceptions of justice and right "inborn" in their minds, informed by the moral intellect to distinguish between right and wrong. In Luther's treatment of natural law, the emphasis is not so much on man's faculties and their properties, but rather on God's Spirit engendering the conscience of natural law (as well as duty and ultimately liberty) in man's heart. In all men, therefore, there is the longing for free- 
dom: however, only the evangelical mind, through the Word, faith and love, is truly able to experience the freedom of conscience which can liberate men from the slavery of the devil, unbelief and the law.

Calvin's references to natural law also reflect the absence of clearly defined meanings attached to the terms ius naturae, ius naturale, lex naturae and lex naturalis. Esau's right of the eldest son, to Calvin, exists in terms of the lex naturae, whilst the psalmist in Psalm 24 pronounces God to be the King of the whole world, to let all men know that, even by the law of nature (ius naturae), they are bound to serve Him (Op. 31:243 (Commentarius Psalmorum, Psalmus 24)). ${ }^{34}$ Elsewhere Calvin expounds the principle that man is totally reliant on Christ, the sovereign King of heaven and earth, as a result of which we belong to Him both by the right of nature (droit de nature or ius naturae) (Op. 17:193 (Epistolae, annos 1558-1559; no. 27833150). 35 To Calvin the lex naturae is the totality of inborn practical and moral principles in man. In his commentaries on the Epistle of St. Paul to the Romans (2:14-16), Calvin observes that there is no nation so lost to everything human, that it does not keep within the limits of some laws. Since all nations, of themselves and without monitor, are disposed to make laws for themselves, it is beyond all question evident that they have some notions of justice and rectitude, which the Greeks call perceptions, and which are implanted by nature in the hearts of men (Op. 49:37 ff. (Commentarii Romanos et 1 Corinthios)). 36

Included in the concept of the lex naturae is the reality of God's existence and the necessity to worship Him, as well as the principle of immortality. In his commentaries on Romans 2:15 Calvin remarks

34 "In summa, Deum totius mundi regem esse praedicat, ut ipso naturae iure cuncti mortales ad eius cultum sint obstricti ...".

35 “... veu que non seulement nous sommes du tout a luy tant du droict de nature que pour le pris inestimable de son sang quil na pas espargné pour nostre salut ...".

36 "They have then a law, though they are without law: for though they have not a written law, they are by no means wholly destitute of the knowledge of what is right and just; as they could not otherwise distinguish between vice and virtue; the first of which they restrain by punishment, and the latter they commend, and manifest in their approbation of it by honouring it with rewards. He (Paul) sets nature in opposition to a written law, meaning that the gentiles had the natural light of righteousness, which supplied the place of that law by which the Jews were instructed, so that they were a law to themselves." 
that the gentiles prove that there is imprinted on their hearts a discrimination and judgment by which they distinguish between what is just and unjust, between what is honest and dishonest. St. Paul does not mean that it was engraved on their will to the extent that they pursued it, "but that they were so mastered by the power of truth, that they could not disapprove of it. For why did they institute religious rites, except that they were convinced that God ought to be worshipped? Why were they ashamed of adultery and theft, except that they deemed them evils?" (Op. 49:37 (Commentarii Romanos et 1 Corintios)). ${ }^{37}$ The term "heart" is used by Calvin as a synonym for the "understanding", rather than for the "seat of the affections". Furthermore there is in men no full knowledge of the law, "but that there are only some seeds of what is right implanted in their nature", evidenced by such acts as the institution of religious rites, the punishment of adultery and theft, murder, and the fact that they command good faith "in bargains and contracts". To Calvin, St. Paul in Romans 2:15 alludes to conscience because the testimony of one's conscience is equal to a thousand witnesses. By the consciousness of having done good, men sustain and comfort themselves; those who are conscious of having done evil, are inwardly harassed and tormented. There is a certain knowledge of the law by nature, which says, "This is good and worthy of being desired; that ought to be abhorred" (Op. 49:38 (Commentarii Romanos et 1 Corinthios)). St. Paul, says Calvin, "intelligently" defined conscience in terms of reason come to our minds, by which we defend what is rightly done, "and that there are those which accuse and reprove us for our vices" (Op. 49:38 (Commentarii Romanos et 1 Corinthios)).

To Calvin the fount of the moral law is not cosmic nature as such, or the naturam rerum (the nature of things), but human nature, the "heart", which is identical to reason, wherein God had infused the norms of justice and equity. The origin of the practical moral law in Calvin's theology cannot be depicted as an objective reality, a permeating cosmic law in man's rational faculty. Rather "conscience" is the distinguishing spirit of man, reflecting God's judgment together with the internal inclination in man that drives man before the throne of God - it is an accusing witness in man; it occupies a middle place between God and man, "not suffering man to suppress what he

37 "Non enim intelligit, insculptum eorum voluntati ut appetant et studiose persequantur, sed quia sic veritatis potentia vincuntur ut non possint non approbare. Cur enim religiones instituunt nisi quia Deum colendum iudicant? Cur scortari et furari pudet, nisi quia utrumque malum censent?" 
knows in himself, but following him out until it brings him to conviction". Calvin continues: "Simple knowledge, therefore, might exist in a man, as it were shut up", and therefore the sense which drives men before the judgment seat of God has been placed over him as a sentinel, to observe and spy out all his secrets, that nothing may remain buried in darkness. Hence the old proverb, "conscience is a thousand witnesses" (Op. 2:896; Inst2.; Bohatec (1934:7 ff.) draws the conclusion that the immanent ability to distinguish between right and wrong is the conscience, described as the ratio (reason); it is a natural gift which was not eradicated by sin; it is a sign of the immortal spirit in man which was not wholly destroyed by the fall. In his Institutio Religionis Christianae (Op. 2:196; Inst2.), Calvin, for example expresses his faith in man's reason, although "smothered by clouds of darkness", still shining forth "to good effect", as the sense "by which man discerns between good and evil, and by which he understands and judges", being a natural gift, "it could not be entirely destroyed; but being partly weakened and partly corrupted" (Op. 2:196; Inst2.). Therefore, in the perverted and degenerate nature of man there are still some sparks which show that he is a rational animal, and that he differs from the brutes, inasmuch as he is imbued with intelligence; there has been implanted in the human mind a certain desire for investigating truth, to which it never would aspire unless some relish for truth antecedently existed, "(t)here is, therefore, now, in the human mind, discernment to this extent, that it is naturally influenced by the love of truth, the neglect of which in the lower animals is a proof of their gross and irrational nature" (Op. 2:196; Inst2.). The implications of man's natural endowment with reason are of profound importance for law, politics and man's social life generally: since man is a social animal, he is disposed, "from natural instinct", to cherish and preserve society; the minds of all men have impressions of civil order and honesty; every individual understands how human societies must be regulated by laws, and also is able to understand the principles of those laws, hence the universal agreement in regard to such subjects, both among nations and individuals, "the seeds of them being implanted in the breast of all without a teacher or lawgiver" (Op. 2:196; Inst2.). In his Praelectiones in ezechielis prophetae Calvin observes that since God's law is written on the hearts of all, we naturally distinguish between good and evil; but if we think how greatly our stupidity is concealing our faults, we shall not wonder that the prophets uttered this command, to lay open our abominations to ourselves (Op. 40:335; Inst2.). ${ }^{38}$ 


\subsubsection{Natural law as the basis for connatural rights in the theology of Luther and Calvin}

Because Luther is more concerned with considering the evangelical message of the gospel concerning man's relationship with God and towards his neighbour, he does not provide a systematic exposition on the rights presupposed by his analysis of duty. However, the duties contained in the divine moral law could easily be translated into fundamental rights correlatively attached to the duties contained in the Ten Commandments. In his Large catechism (1529), ${ }^{39}$ Luther's remarks on the first commandment, to the effect that each person should "be in his station in life according to God's order", could only be effectively protected by means of the fundamental right to serve God (LC 1:47); the second commandment, demanding truly good works by which God is praised, truth and justice established, falsehood refuted, people reconciled, obedience rendered and quarrels settled, gives rise to the right to praise God, to establish truth and justice, et cetera (LC 1:65); the third commandment's appeal to sanctify the holy day, brings in its wake the right to worship God, and that men may have the time and opportunity to do so in order that "a common order will prevail and no one will create disorder by unnecessary innovation"; the fourth commandment's duty to honour one's father and mother carries with it the right do obey and serve those in office (LC 1:141 ff.); the rights presupposed by the fifth commandment include those to be defended, delivered and protected from the wickedness of others, because this commandment, says Luther, acts as a "wall, fortress, and refuge" to protect the neighbour from harm and injury (LC 1:185); the sixth commandment entails the right not to have one's spouse dishonoured, and in an extended sense it contains the right not to be harmed by others in any way (LC 1:200); the seventh commandment provides men with the right to protect (and have protected) their property; besides our own bodies, our spouses, and our temporal property (LC 1:223 ff.), the eighth commandment provides the right which is "indispensible" in protecting our honour and good name, selfrespect, et cetera before our spouses, children, and neighbours; the "first application" of this command being that everyone should help his neighbour maintain his rights, and that he must not allow these

omnium cordibus lex Dei: et ita naturaliter discernimus inter bonum et malum: sed si reputamus quantus sit stpor noster in tegendis nostris vitiis, nonmirabimur prophetas cum hoc mandato pridire, ut scilicet abominationis nostrae nobis patefiant." 
rights to be thwarted or distorted but should promote and "resolutely guard them". Here we have a perfect goal set for our jurists: "perfect justice and equity in every case" - they should "let right remain right, nor perverting or concealing or suppressing anything on account of anyone's money, property, honour, or power" (LC 1:255 ff.); the ninth and tenth commandments provide the "right" to maintain the general application of these commandments, to the extent that we are commanded not to desire harm to our neighbour, nor become accessory to it, nor give occasion for it", and we are to leave him willingly what is his, "and promote and protect whatever may be profitable and serviceable to him, as we wish that he would to us" (LC 1:313). The Ten Commandments provide "doctrine", or "social order" for mankind to aspire to.

Luther's discourse on the duties contained in the Ten Commandments reflects the principle that fundamental rights are primarily located within his broader approach towards moral duties. These duty-based rights in Luther's theology serve two important functions: firstly, they presuppose that man has rights in order to discharge duties towards God and his fellow-men; secondly, the most fundamental right anyone can have is the right to freedom of conscience, based on man's conscience of freedom. Implicitly this means that conscience itself does not have an absolute freedom, but that the human conscience as "natural faculty", has the absolute right to distinguish between right and wrong, subject to the divine will. The fundamental (or "connatural") right to freedom of conscience presupposes the authority to act, protected by the moral law, which obliges others to respect that faculty.

Different from Luther, Calvin proceeds from man's rational nature as the point of departure for the moral-legal religious and intellective acts performed by mankind. This entails that the law of nature may not be disturbed, because it flows from the ancient source of nature and is grounded in the unassailable principles of all laws. The prohibition of incestuous connections out of wedlock, for instance, provides for Calvin an example of the principle that what is natural cannot be abrogated by any consent or custom. The prohibition of incest flows from the fountain of nature itself, and is founded on the general principle of all laws, which is perpetual and inviolable (Op. 24:662 (Commentarius Exodus. Praefatio in Legem)). To Calvin the "purity of nature" reflects the "statutes of God" (Op. 2:662; Inst2.). However, not only natural laws are deduced from nature, but also the natural rights of freedom, and the subjective personal and property rights which are unspoiled, ancient and original because they 
flow from nature. So, for example, life is a fundamental good, and the right of property is deducible from nature, because nature teaches that the possession of property must be respected as if it were holy. The person interfering with the right of property transgresses against the order of nature and sins against the basic law of equity. In his comments on Exodus 19:14, Calvin condemns theft, because everyone's property must be secure, and therefore "it is necessary that the land-marks set up for the division of fields should remain untouched, as if they were sacred" (Op. 24:676 (Commentarius Exodus. Praefatio in Legem)). To Calvin, nature has always taught us the principle that if bounds and limits are not kept and maintained, "there would be horrible confusion among men, and no laws would be any longer kept" (SOD. 114:697(2); Deuteronomy 19 (7.12.1555)). To transgress on the land of another amounts to the berating of the order of nature (SOD. 114:698(1); Deuteronomy 19 (7.12.1555)). The rule of charity demands that everyone's rights be safely preserved, and that those thieves who secretly steal the property of others, those who seek gain from the loss of others, those who accumulate wealth by unlawful practices, and those who are more devoted to their private advantage than to equity, all practise actions which all people abhor as disgraceful (Op. 24:669). Therefore the person interfering with the right of property harms the order of nature and sins against the foundational law of equity. Freedom is valuable and robbing someone thereof is evil. In his commentaries on Deuteronomy 21:14-17, Calvin refers to liberty, "which is called an inestimable blessing" (Op. 24:709 (Commentarius Exodus. Praefatio in Legem)), 40 and to deprive a person of such a great blessing, "was almost to destroy him" (Op. 24:628 (Commentarius Exodus. Praefatio in Legem)).

\section{The implications of Luther's and Calvin's views on God's providence, conscience and social benevolence}

\subsection{Providence and conscience}

Both Luther's and Calvin's theories of natural law and natural right are solidly embedded in their respective views of the providence of God and His providential care and love for mankind. Therefore submitting oneself to the care of divine providence is the first step vocatur inaestimabile bonum) solatii non vulgaris loco fuit". 
towards understanding man's role, function and moral commitment towards his fellowmen. $\mathbf{4 1}$ Absolute confidence in God, together with a complete independence from everything on earth that offers gratification, power or fame, and loving God above everything else, implies the living faith needed to gain insight into God's providential care for and ordering of the universe. Luther has an appreciation of the fact that all things in the world, great and small, are in the hands of our heavenly Father and that they operate only as He disposes for the accomplishment of his wonderful plans. Faith in the infinite goodness, mercy, munificence and generosity of our heavenly Father who in everything works for the good of those who trust in Him, and whose gifts, favours, graces and care are in proportion to the confidence his beloved children place in Him, provides human beings with the power to withstand the devil in its battle for supremacy in the human conscience.

Conscience to Luther is the judgment by which we come to know the moral value of our actions. Conscience as a reflection upon the moral worth of our actions, does not cause but evaluates the moral content (or nature) of what we do. Therefore, conscience is not and cannot be the fundamental source of morality in our lives, and is itself subject to the moral law. Blinding oneself to the moral content of our actions and making false judgments about them, will produce flawed and immoral judgments, ending in our telling ourselves that what is right is actually wrong, or that what is wrong is right. The flawed conscience, in spite of the immutability of the principle of universal love and its undeniable obligations to duty, produces theories of human autonomy and/or the mutability of the moral law.

Although the moral law of truth is impressed on the conscience of all men, the light of judgment in man is dimmed as a result of sin. Therefore man needs God's spirit of liberty to wrest us from the bonds and shackles of sin and its oppressive bondage of man's faculties. Through God's Word, faith and the Holy Spirit, man's upright or "good" conscience is able to appreciate God's moral law for what it is and to submit to its demands of benevolence.

Whereas Luther's views on man's liberty of conscience, flowing from man's conscience of freedom, and the need for natural law in God's providential government of the world are more "forward-looking", Calvin is inclined to look "backwards", in so far as God's redemptive 
work, through his Word and Spirit, enables us to more clearly perceive the original creational order and purpose with creation and the principles of natural law. Calvin leaves more scope for man's natural inclinations and reason to penetrate the layers of sin and darkness covering the human being's comprehension of God's providential wisdom with creation and society.

\subsection{Natural law, moral duty and jural right}

The views of Luther and Calvin are arguably closer on the issue as to what the relationship between natural law and morality is. To both Luther and Calvin, morality attached to persons, commands and obligations without compromise. Morality binds persons irrespective of any effect it may have on them, thereby determining human actions with the force of obligation. The first moral law demands the love of God above all and the love of one's neighbour as oneself. This moral law, which is common to all individuals irrespective of race, sex, nation, culture or religion, binds everyone without exception. The moral law reflects the correlative entwinement of duty and right: the most basic social duty is the duty of benevolence; the most basic right is the right to benevolence. Translated into the various social contexts of human existence, the moral law reflects various fundamental rights for the performance of man's duties. In this regard Calvin is much more explicit on the issue of the "natural rights" emanating from man's fundamental duties.

Both Luther's and Calvin's views on natural law entail that man is both a profoundly moral and social being - from man's coming into existence, through man's involvement in creation and functioning in society, man is a moral being involved in social relationships subject to the duties and rights reflected by the moral law. From the angles of man's social involvement and man being subject to the moral law, the essence of right can be described as the faculty to act freely, protected by the moral law which obliges others to respect that faculty. In other words, the person's obligation to be just ensures for him the right to act within the limits of justice. His duty to act in accordance with justice imposes on others the duty to respect this obligation. The co-related nature of duty and right implies that there can be no right in one person without a corresponding duty in others to respect that right. The duty, for example, to worship God, gives rise to my right to worship God, a right which others have a duty to respect. On the other hand, the concept of duty is anterior to that of right and as such does not necessarily give rise to rights in others. 
For example, my duty to worship God does not necessarily imply that other's rights are violated if I do not worship God as I should.

The differences between moral and jural duties is important to bear in mind. The following explanation will suffice: when we sacrifice that which is ours by right for the sake of someone else, we act benevolently because we are not bound under any jural obligation to make this sacrifice either to spare the other person from the greatest possible evil or to procure for him the greatest good. This implies that under the moral law of mutual benevolence there is nevertheless an obligation to do this, as Cicero aptly states: "(W)e are not required to sacrifice our own interests and surrender to others what we need for ourselves, but each one should consider his own interests, as far as he may without injury to his neighbour's" (Off. 3.10). In effect this means, for example, that if a person enters an athletics race, it is his duty to exert himself with all his strength and to strive with all his might to win; but he ought under no circumstances to trip or in any other manner foul his competitors. Similarly in society it is not unfair for anyone to seek to obtain what is needful or useful for his own advantage, but he has no right to take it from his neighbour by force. Therefore, there is always infringement of right, always violation of natural law (the moral-jural law) when we force others to make sacrifices for us or to cause harm to third parties (cf. Off. 3.10).

The implications of duty-based rights in Luther's and Calvin's natural law views have additional implications: firstly, knowingly preventing good to others or causing them harm with actions that bring the performer of such activities no advantage whatsoever, but which are exercised under the pretext of using his ownership, boils down to acting injuriously, invalidly and vainly because it is not sanctioned by the moral law. In addition there is no obligation in others to respect the freedom of those actions or the ownership on which they rest. Secondly, action which avoids harm to oneself or obtains some good without harm to others or impediments to their good, does no injury to another's rights and consequently such activity is always jurally lawful and valid.

\subsection{Human rights and divine right}

Luther's and Calvin's views on human rights and divine right imply that in the widest sense jural duty forbids de facto injury, as well as any attempt to do injury to another's faculties. Therefore a person who neglects or refuses to carry out some act of benevolence imposed by the Creator, does not damage any jural duty towards 
human beings, but is guilty relative to God, who may demand the fulfilment of the divine moral precepts. Furthermore, the duties of benevolence if considered as imposed by the light of reason or dictates of conscience alone, cannot be called jural duties. If human rights were to come into collision with God's divine rights, the former would cease to be rights because they would be ipso facto immoral. Therefore, human rights are subject to, conditioned by and of a lower order than divine rights.

Human rights appear in the sphere of moral freedom - there can be no true rights forbidden by the moral law. It should be noted though, that right is more than lawfulness, in so far as it denotes a certain governance to act in relation to other people, formed by the moral law itself which grants freedom of action to a person and prohibiting others from interfering with that action.

\section{Conclusion}

Martin Luther's and John Calvin's views on natural law were foremost the results of their opposition to the scholastic emphasis on reason in favour of love as the synthesis of reason and will. However, their opposition to Aristotle's legacy of rationalism in scholastic legal philosophy does not mean a wholesale rejection of the Thomistic synthesis of reason and revelation. Firstly they did aspire to reinterpret Thomas's views on natural law and natural rights in the light of the emergent evangelical perspectives on faith, the Word, and the working of God's Spirit in creation. Secondly, their re-interpretation of Thomism reverted to Cicero's emphasis on duty, nature and right. Together with their evangelical perspectives, Luther's and Calvin's Ciceronian re-interpretation of Thomism, produced important perspectives for establishing the moral context of natural rights and duties.

Two matters of particular importance have to be taken into consideration in developing the "connecting points" provided by Luther's and Calvin's natural law views: firstly, the battle for human (or connatural) rights does not in the first place take place in the public square, but in the conscience of man and his fundamental experience of freedom. Secondly, the freedom of conscience as a result of man's liberation from sin and the bondage of his faculties empowers, motivates, commits and drives us towards understanding, honouring and experiencing the duties and rights emerging from the folds of the moral law - a most satisfying experience for the believer! 


\section{List of references}

ANON. 1814. Das Noth- und Hülfs-Büchlein. 1.Teil. Gotha: Beckerschen Buchhandlung.

AQUINAS, T. 1997. Summa Theologica. Albany: Ages Software. (The Master Christian Library: Books for the Ages.)

ARISTOTLE. 1977. Ethics. Harmondsworth: Middlesex.

ATT

see CICERO. 1925-1928

BK

see LUTHER, M. 1958-1967

BOHATEC, J. 1934. Calvin und das Recht. Graz: Verlag Hermann Böhlaus Nachf.

CALVIN, J. 1530. Institutes

see CALVIN. 2005

CALVIN, J. 1559. Institutes see CALVIN. 2005

CALVIN, J. 2005. Opera. Vols. 1-59. Ed. by H.J. Selderhuis. Apeldoorn: Instituut voor Reformatieonderzoek.

CAT

see CICERO. 1937

CICERO, M.T. 1921. De Finibus Bonorum et Malorum. London: Heinemann.

CICERO, M.T. 1925-1928. Letters to Atticus. London: Heinemann.

CICERO, M.T. 1928. De Officiis. London: Heinemann.

CICERO, M.T. 1931. Oratio in Pisonem. London: Heinemann.

CICERO, M.T. 1937. The Speeches: In Catilinam. London: Heinemann.

CICERO, M.T. 1938. Philippics. London: Heinemann.

CICERO, M.T. 1943-1954. The letters to his friends. 3 vols. London: Heinemann.

CICERO, M.T. 1948. De Re Publica \& De Legibus. London: Heinemann.

CICERO, M.T. 1951. De Natura Deorum. London: Heinemann.

CICERO, M.T. 1979. Oratio pro Cluentio. London: Heinemann.

CLU

see CICERO. 1979

ESSER, P.H. \& PRINS, P. 1947. Het geweten. Kampen: Kok.

FAM

see CICERO. 1943-1954

FIN

see CICERO. 1921

INST

see CALVIN. 1530

INST2

see CALVIN. 1559

LC

see LUTHER, M. 1958-1967

LEG

see CICERO. 1948

LUTHER, M. 1883-1987. Werke: kritische Gesamtausgabe. 78 Bde. Weimar: Hermann Böhlaus Nachfolger.

LUTHER, M. 1958-1967. Works. American edition. 55 vols. Eds: J. Pelikan (vols. 1-30) \& H. Lehmann (vols. 31-55). Philadelphia: Concordia. 
LUTHER, M. 1963-2005. Ausgewählte Werke. Red. H.H. Borcherdt \& G. Mertz. München: Kaiser. (Bd. 1-6 \& Suppl. Bde. 1-7.)

LW

see LUTHER. 1958-1967

McNEILL, J.T. 1941. Natural law in the thought of Luther. Church history, 10:211-227.

McNEILL, J.T. 1946. Natural law in the teaching of the Reformers. Journal of religion, 26:168-182.

ND

see CICERO. 1951

OFF

see CICERO. 1928

OP

see CALVIN. 2005

PHIL

see CICERO. 1938

PIS

see CICERO. 1931

RAATH, A.W.G. 2005. Writing "new" decalogues: Martin Luther's development of the Pauline-Augustinian tradition of natural law. Koers, 70(3):425-454.

RAATH, A.W.G. 2006a. Rights of love and the dynamics of social benevolence: a constructive interpretation of Martin Luther's thoughts on social rights. Acta academica, 38(3):1-44.

RAATH, A.W.G. 2006b. The justness of love: the essence and status of justice in Luther's theology. Studia historae ecclesiasticae, 32(1):335-354.

SCHOLLER, H. 1981. Martin Luther on jurisprudence - freedom, conscience, law. Valparaiso University law review, 15:265-282.

SCHREINER, S.E. 2001. The theatre of his glory: nature and the natural order SOD in the thought of John Calvin. Grand Rapids: Baker Book House.

see CALVIN. 2005

ST

see AQUINAS

VAN DER VYVER, J.D. 2005. Menseregte en menswaardigheid. Koers, 70(3): 455-471.

WA

see LUTHER. 1883-1987

\section{Key concepts:}

human rights

justice

Luther, Martin

natural law

Kernbegrippe:

geregtigheid

Luther, Martin

menseregte

natuurreg 